\title{
The Research of "Double-qualified Teachers” Based on Engineering Majors
}

\author{
Xie Yaya \\ School of Electronics and Information Engineering, Jingchu University of Technology, \\ Jingmen 448000,China \\ 3353302@qq.com
}

Keywords: double-qualified teachers; engineering majors; training ways

\begin{abstract}
Nowadays, "Emphasis on practice rather than theory" is a common phenomenon in higher engineering college, so the urging for double-qualified teacher in higher engineering college is put forward. On the premise of clearing the connotation of "double-qualified", putting forward the training ways and measures of double-qualified teacher, namely transforming the educational concept and model of engineering education, strengthen the engineering education of teachers, introducing higher engineers and technicians in scientific research institution or enterprise, emphasis on practicing and reducing theory teaching workload, making policy of post appointment and so on.
\end{abstract}

\section{Introduction}

It is an important part of higher education to train the personnel in engineering colleges. The quality of the personnel trained in engineering colleges not only directly affects the overall quality of higher education, also affects the process of socialist modernization construction in our country. Since the new China founded, especially since the reform and opening up, Chinese engineering education obtained the rapid development of higher universities and colleges of undergraduate course, the quality of personnel training basically can satisfy the demand of the rapid development in social and economic for engineering and technical personnel, it played a vital role in the development of the society. For engineering majors, the personnel training in the teaching practice occupies the important position, it is the key link in teaching, and the important link about students' theoretical knowledge transformation. Courses in colleges and universities teachers have rich theoretical knowledge, but due to the lack of work experience in the enterprise, emphasis theory on rather than practice. It also leads to the problem that it is difficult for graduates' employment and enterprises' employer. Therefore, it is imperative to implement a class teaching pattern of double-qualified teachers.

\section{The necessity and urgency of training the double-qualified teachers in engineering majors}

The situation of emphasizing theory on rather than practice has existed for a long time in higher engineering education in China, students learned more theoretical knowledge than engineering practice training, graduates are lack of modern engineering design ideas, methods, and the integrated use of various knowledge ability to solve engineering problems, course design and graduation design from the engineering practice, is more of a theory, design the results of technical and economical efficiency are not reasonable, it cannot be applied in engineering practice. Because it is break away from the social demand, and the enterprise is not close to it, the communication is not enough, engineering education is difficult to produce all kinds of specialized personnel for the needs of national economic and social, which is contradictory with the ministry of education's idea about "guide under the social demand, strengthen the practice teaching, and improve the practical ability of college students". 
In addition, the forefront of engineering course teacher should understand the professional information technology and the new research results, in order to improve the teaching effect of teachers in the classroom. Because engineering curriculum has the very strong practicality and pertinence, if there is no engineering practice, the teacher in the classroom can be scripted, the theory and practice from the phenomenon is widespread in the colleges and universities, it is also one of the urgent problems in engineering colleges.

There are two main aspects caused the above problems.(1) the teachers lack of engineering background, the teachers troop quality can't satisfy the needs of cultivating engineering and technical personnel. As a result of college expansion, many universities introduced a master or doctor degree of young teachers, young teachers in the direct access to the work of colleges and universities after he graduated, namely "just out of school, into the school gate again ", without the experience of manufacturing or engineering line actual exercise, lack of necessary engineering practical experience, it is difficult to truly touch the engineering practice in the process of teaching, even after into the internship site, there are a lot of facilities and equipment to learn, they can't speak to students a lot.(2) During the talents' introduction, high engineering college and university are devotion to education, to master, doctor, while ignoring the senior engineering and technical talents with rich engineering experiences. At the same time, colleges and universities also lack of effective mechanism to attract enterprises with rich practical experience, and suitable for engineers and senior engineers engaged in the work of teaching to the school to teach for students.

In view of the above problems, in order to adapt to the current society on the requirement of engineering and technical personnel, the urgent need of higher engineering education has not only solid professional theory knowledge, but also has rich experience in engineering practice of the "double-quality" teachers, to change the current situation of engineering education which can't meet the demand of society, let the higher engineering education "to return to project". Pays too much attention to the higher engineering education from engineering theory to attach importance to the engineering practice, strengthen the cultivation of students' engineering practice ability. In addition, the "double-quality" teachers generally have relatively close relationship with enterprises' employer, it can broaden employment channels for graduates, to promote students' employment in today's increased pressure.

\section{The connotation of double-qualified teachers in engineering majors}

The concept of "double-qualified" teachers is proposed by the ministry of education for the vocational colleges, which is put forward to strengthen practical teaching link, promote the organic combination of theory teaching and practice teaching.

For the "double-qualified" teachers basically has the following two kinds of understanding.

The traditional "double-qualified" teachers are understood as "double-title" teachers or "double-certificates" teachers.

From the school teacher title appraisal and other professional title evaluation, The ministry of education puts forward the concept of "double-qualified teachers ", according to the actual situation of considering the actual needs of the professional teachers' quality, "double-qualified teachers" teachers refers to a lecturer (or above) professional titles, and meet the following conditions, one of the full-time teachers: (1) with the intermediate (or above) professional practical work and technical titles (including industry charter qualification certificate).(2) the past five years have 2 years working experience in the first line of the professional enterprise actual, or to participate in teachers' professional skills training for the ministry of education certificate, can guide students comprehensive professional practice training activities. (3) in recent five years host (or participation) two main application technology research, the results have been used by enterprise, and the benefit is good. (4) in recent five years host (or major) two campus practice teaching facilities or enhance the level of technical design and installation work, the use effect is good, get the advanced level of similar colleges and universities in the province. 
For engineering schools, "double-qualified teachers" standard is the core of the practical work ability, practical work experience and application technology research, practice teaching facilities construction, are proof of teachers' practical work abilities. Literature [4] proposes the engineering colleges and universities "double-qualified" teachers should firstly have the conditions: (1) is a university lecturer title or above 3 years teaching experience, and in the first ten years in the industry or enterprise production, service, management, the first line of the professional 3 years (can be accumulated) full-time working experience, and get the professional technology of intermediate above major position (including industry charter qualification certificate).Above title (2) with the university teachers, and in the first five years in the industry or enterprise production, service, management, the first line of this professional more than 2 years can be accumulated practical work experience, at the same time to participate in the relevant authorities (ministry of education, the ministry of labor, etc.) teachers' professional skills training to obtain certificate of the organization.(3) has a college lecturer above title, presided over nearly five years (or major) two application technology research projects, the engineering application, development projects, the results have been used by enterprise, benefit is good.(4) has a college lecturer above title, presided over nearly five years (or major) two campus practice teaching facilities or enhance the level of technical design and installation work, use effect is good, of similar colleges and universities in the province in the advanced level.

The author thinks that, for the "double-qualified teachers" of high engineering college and university teachers should not only meet the above requirements, but also consider its engineering practice experience of timing, because with the development of technology, equipment and the improvement of quality of engineering and technical personnel, new construction technology and specification. For engineering education, only to teach students the latest and cutting-edge engineering practice is the guarantee under the social needs to cultivate professional and technical personnel.

\section{The way and measure of training double-qualified teachers in engineering majors}

\section{Change the concept and model of engineering education}

Change the existing idea "Emphasis on theory rather than practice" in engineering education is the important premise for the training of "double-qualified" teachers. Engineering colleges and universities is in an urgent need to prevent engineering education academic and theoretical orientation, pay attention to engineering and the practical application, attach importance to cultivate the students' engineering consciousness, engineering interest, ability, exploring the unique training mode of engineering education.

\section{Strengthen the teachers' scale of engineering education in engineering colleges and universities}

With the sustained and rapid development of higher education, the teachers' scale of the universities is expanding, which is full of a large number of young university teachers. Their degree is high, the solid professional knowledge, active thinking, strong ability to adapt, brought new vitality for the modern engineering education. But the engineering practice background is weak to most of these young teachers, which is very adverse to the cultivation of the ability of engineering students project. Therefore, the engineering colleges should establish university-industry cooperation as the main characteristics of engineering course teacher training system, to strengthen the engineering ability and quality of teachers, especially young teachers. The author suggested to establish special rules and regulations in colleges and universities, protect young teachers from capital, time, to the enterprise field practice, increase practical work experience, improve the ability of practice teaching. First, engineering colleges should set up production, training funds, support engineering teacher paid annual bring benefits to the enterprise training, enterprise can be contacted by the school or teachers. Second, we must ensure that the teachers' training time, the time teachers go to refining enterprises or production line can be set from three months to half a year, of course, teachers also can make full use of summer and winter vacation time. Through touching the enterprise field and carrying out the 
production work, to understand the manufacturing or engineering practice, improve the ability to solve practical engineering problems to ensure and promote the closely integration with the engineering practice and engineering course teacher, and constantly improve their "double-qualified".

The introduction of senior engineering and technical personnel in scientific research institutes and enterprises

Engineering colleges and universities should study and formulate the corresponding policy, attracting the personnel with high academic level and strong practical ability from scientific research institutes and enterprises to teaching work. This kind of senior engineering and technical personnel are usually have corresponding professional theoretical knowledge and practical experience. However, because of the different job in the professional, they must move from the role of "I can do" to "I can teach". Before teaching, we should get them to the quality of teachers training, such as education related courses such as education, education psychology, daily management and learn all kinds of rules and regulations of the school. Before the teaching level and skills can not meet the corresponding levels, they should not be engaged in teaching work too much, but can be familiar with work by listening class. It can make up for the insufficient number of "double-qualified" teachers, not only expand the scale of school teachers, and effectively stimulate the vigor of the education resources.

In addition, we should actively introduce experts, scholars, senior engineering and technical personnel who have rich practical experience to colleges and universities to give lectures or some frontier courses teaching tasks; At the same time, enterprise technology experts can be invited to participate in school internship practice, as the guidance of graduation thesis (design), etc.

\section{Reduce teachers' theoretical teaching work, strengthen the scientific research practice}

As a result of college's students expanded and reform of teaching, it still exists a phenomenon in some colleges and universities that teachers have heavy workload and too much new curriculum is wait for them, which directly lead to that the teacher don't have the energy to be engaged in the forefront of research and study the professional knowledge, make the teaching theory with practice. At present some schools have stripped-down the curriculum content, optimized the curriculum system, and reduced the repetition of the courses, provided more sufficient scientific research practice time for teachers, so that they can constantly improve the scientific research practice ability, learn more knowledge of this major cutting edge and make the class content more rich, and stimulate the students' interests.

\section{Formulate corresponding supporting policies}

Engineering colleges should put the construction of "double-qualified" teachers into the overall school education development planning, and establish the policy for engineering teachers, senior engineering and technical personal.

First of all, we should develop a specific engineering education plan according to the school teachers' title structure and combined with teachers' qualifications and experience, ensure the engineering education opportunity and effect of teachers, especially the young teachers.

Secondly, the position of employment should be inclined to "double-qualified" teachers. It is clearly put forward in the national medium and long-term education reform and development plan outline (2010-2020), "the outstanding engineers training plan must be implemented in the colleges and universities". On June 23, 2010, the ministry of education put forward "outstanding engineers training plan" in Tianjin, reform and improve the teachers' position appointment of the project and appraisal system. The employment of professional teachers in colleges and universities should be evaluated by engineering project design, patent, technology cooperation between production and service, it is prior appointed the teachers who have work experience in the enterprise.

\section{Summary}

The cultivation of "double-qualified teacher" in engineering colleges is an urgent need to solve the problem in our country engineering colleges currently, is the guarantee to train personals who are 
satisfied the demand of the social by higher engineering colleges and universities. Through the study of the engineering education, the introduction of scientific research institutes and enterprises senior engineering and technical personnel, and formulating the corresponding policy, teacher's "double -qualified" can be continuously strengthened by the colleges and universities.

\section{Acknowledgements}

Research on Provincial Teaching Reform in Hubei Province in 2016.

"Study on the school enterprise docking and integration of Electrical Engineering Specialty in local colleges and universities”, Project number:2016423.

\section{References}

[1] Zhu Chunyu, Zhu Benkun. The Research of the Measure to Construct "Double-qualified" Teacher Group Based on Engineering Majors [J]. Xue Li Lun, 2008(22):57-58.

[2] Xu Jun, Qin Liang, Liang Tao. The Build for the Teaching Mode of Double-qualified Teacher [J]. Journal of Shanxi Coal-Mining Administrators College, 2014, 27(4):114-115.

[3] Yang Bo, Zhang Rui. Journalistic English Teaching Reform from the Perspective of "Double-Qualified Teachers"[J]. Journal of Heilongjiang College of Education, 2016, 35(10):141-143.

[4] Kang Yan. The study to the "double-qualified" teachers training in applied university [J]. Journal of Shandong Youth Administrative Cadres College, 2008, (4):86-87.

[5] Li Haihua, Bai Guoqiang, Zhu Tiequn, Liu Suixian. Study of Ability-oriented Engineering Literacy Training Models - teachers in higher engineering college need Academic-practical quality [J]. Grain Distribution Technology, 2014(4):45-47. 